re-catalogued. Ten type specimens of fossil brachiopoda and a crushed specimen of Liparoceras cheltiense from the lower Lias of Battledown Brickworks, Cheltenham, have been transferred to the British Museum (Natural History).

\section{City Museum, Sheffield}

THE annual report of this progressive Museum for 1963-64 records that work has commenced on the longterm project of compiling a card-index of all published references to the natural history of the Sheffield region (Pp. $23+8$ plates. Sheffield: The City Musoum, 1965). Even in its early stages it is proving valuable to the Musoum staff in dealing with enquiries, and eventually it should prove equally valuable to research workers and members of local societies. An unusual feature in an annual report is a chronological survey of table cutlery. The compendium eovers the typology of cutlery, especially knives, from the tenth to tho twentieth century. It is fully illustrated and the dating will be of interest for its own sake and for the light which it may shed on the date of associated items or structures. Sometimes, an estimate of the date of manufacture of a knife which is featured in a painting or drawing may assist in determining the age of the picture. Likewise, the representations of knives sometimes found carved on wood or stone, engraved on metal, painted on ceramios or even embroidered on textiles, may help to date the objects themselves.

\section{Serotine Bats}

THE Earl of Cranbook has reported that, during late June, serotine bats were obscrved to be moving in a more or less discrete group up and down a two-mile stretch of road and feeding on summer chafers (Transactions of the Suffolk Naturalists' Society, 13, Part 1; February 1965). A small number were captured in mist nets. When in pursuit of their prey the bats showed a remarkable facility in avoiding the relatively dense motor traffic along the road; no casualties were observed. All the bats captured were lactating females, although they were identifiable as juveniles by weight and tooth wear. A few noctules flew with the serotines in pursuit of the same prey. The serotines seemed to be affectod more by the weather than were the noctules.

\section{Fruit and Vegetable Dehydration}

AMong the methods of preserving and processing food, that of dohydration occupies an important position. It turned out to be particularly valuablo during the Second World War, and there was an outburst of technical and scientific activity to cope with the demands at that time. After a post-war recession of interest in dehydrated products, they aro now one of the most rapidly doveloping sections in the field of food technology. A good deal of this is due to the pionooring work carriod out at the Ministry of Agriculture, Fisheries and Food factory at Abordeen, especially in developing methods of freeze-drying of foods. The publication of The Dehydration of Fruits and Vegetables-A Review of Methods, by L. P. Hall, is to be wolcomed; this is publishod as Technical Bulletin No, 9 by the Fruit and Vegetable Canning and Quick-Freezing Research Association, Chipping Campden. (The word "Dehydration" could now well be included in their name, or perhaps "Processing" could be substituted for Canning, Quick-Freezing, and Dehydration.) This is a short and competently written survey of existing methods of dehydration. It is sufficiently up to date and comprehensive to include tumbling freezo-drying, as well as fluidbed and belt-trough drying; and oxplosion puffing as a means of pre-heating foods to speed up the actual drying procoss. The excellent descriptions in the booklet (Pp. 16) might have been shortened and improved by a number of diagrams showing tho principles of the various processes. Thero aro useful sections on bacteriological and nutritional aspects of dehydrated fruits and vegetables. The review as a whole is a modol of brevity and clarity. and will be a useful short guide to the subject even after a fuller and more comprohensive account of dehydration methods has been produced.

\section{Descriptions of Pathogenic Fungi and Bacteria}

THE Commonwealth Mycological Institute, Kew, bogan in 1964 to issue a serios of loose-leaf sheets "to provide standard descriptions of pathogens for use by pathologists, particularly those isolated workers with restricted library facilities". These have now reached a very substantial volume of six sets of ten sheets each (price 5s. per set, post free) and it is obvious that they fill a longfelt want not particularly related to restricted library facilities. The first set, moreover, dealt with ten rust diseases of warm region crops, but subsequent sets have described pathogens found over a much wider range of climate. Set 2 considered ten bacterial diseases; Sot 3, Fusarium spp.; Set 4, Phytophthora and Pythium spp.; Set 5, another ten bacteria; and Set 6 , rust diseases of tomperate and tropical erops. Workers at the Institute seem to have selectod for description pathogens which present some difficulty in practice, and their treatment is invariably conciso yet comprehensive. Each pathogon is described in detail, with cultural information where applicablc, with host range, symptoms, geographical distribution, references to literature and most useful miscellaneous notes. Descriptions of fungi are illustrated by at loast two half-tone illustrations which are excellent for the purpose. These sheets save much time in the day. to-day diagnosis of plant pathogens and have a remarkably wide application.

\section{Development and Genetics in Higher Plants}

THE success of modorn research is very dependent on the choice of a suitable experimental material, especially in tho field of development and genetics in higher plants. In this respect the small annual cruciferous plant Arabidopsis thaliana (L.) Heynh. has many advantages, for example, high variability in natural habitats, little space requirement, low demands in culture, rapid generation succession, abundant seed production, readiness for experimental hybridization and autogamy, a polymorphic spectrum of induced mutations, vigorous growth in sterile culture, uvailability of clear phenotypic marker genes and low chromosome number. Therefore in the past decade Arabidopsis has gainod special attention as a model plant in laboratories throughout the world. This fact was confirmed at the first international symposiurn on "Arabidopsis Research", held in Göttingen during April 21-24. The symposium was arranged in five sessions: (1) taxonomy and variation (including ecological distribution, interspecific hybridization, polyploidy and embryology); (2) development (genetic control of differentiation and morphogenesis, seed dormancy, vernalization and flowering); (3) genetics (genetic basis of segregation, linkage, non-meiotic recombination and plastom mutation); (4) mutant analysis (isolation and analysis of biochemical mutants, chlorophyll formation and plastid fine structure in leaf colour mutants); (5) mutagenesis (X-ray-induced embryonic malformations, chimerical structure of $M_{1}$. plants, heterologous tritiated-DNA- and thymidineanaloguo incorporation, induction of recessive lethals and action of various chemical mutagens). 'The versatility of Arabidopsis was thus woll demonstrated by this broad spectrum of subjects as well as by some particularly outstanding experimental results, such as the first proof of mitotic recombination in higher plants, or a detailed insight into the mechanisms of vernalization or the pathway of thiamine biosynthesis by means of nutritional mutants. 'The symposium was cspecially valuable for the exchange of methods and general experiences dealing with the design of experiments with this 'botanical Drosophila'. This was implicit in the twenty-ninc papers and the discussions that follower them from the thirty-five 